\title{
An evaluation of Samarra city drinking water treatment plants
}

\author{
Faris Hammoodi Al-Ani ${ }^{1}$, Eng. Ali Awaid ${ }^{2}$ \\ ${ }^{1}$ Department of Construction Engineering, University of Technology, Building, Iraq \\ ${ }^{2}$ Department of Environmental Engineering, University of Baghdad, Iraq
}

\section{Email address:}

farishamodi@yahoo.com(F. H. Al-Ani), envaliawaid@yahoo.com(Eng. Ali Awaid)

\section{To cite this article:}

Faris Hammoodi Al-Ani, Eng. Ali Awaid. An Evaluation of Samarra City Drinking Water Treatment Plants. International Journal of Environmental Monitoring and Analysis. Vol. 1, No. 5, 2013, pp. 203-212. doi: 10.11648/j.ijema.20130105.16

\begin{abstract}
Global population increases specially in developing countries such Iraq requires more effort and investment in water and sanitation facilities to enhance the welfare of people in meeting the MDG objectives. The competition for water resources coupled with the generation of wastewater is creates additional pressure on the available supplies and increasing pollution level. To address such challenges it has become necessary to build new or enhance existing treatment systems. In different part of Iraq including in Samarra City effort is being made to enhance the water quality in regard to its physical, chemical, and biological characteristics as well as the minerals and organic substances which may produce adverse physiological effects. In order to evaluate different aspect of water quality this study focused on evaluating the drinking water quality and also the performance of the two treatment plants in Samarra City located on the left bank of Tigris River to the north of Baghdad City. The investigation covered the period of December, 2004 to May, 2005. The first is the main conventional water treatment plant with a capacity of $2400 \mathrm{~m}^{3} / \mathrm{hr}$. and the second is a compact unit with a capacity of $200 \mathrm{~m}^{3} / \mathrm{hr}$. The collected water data cover some of the important physical and chemical parameters of water quality; covering temperature, TDS, turbidity, $\mathrm{pH}$ and residual chlorine. While the bacteriological parameters covered total plate count (TPC) and E-coli for stages of treatment plants. The results show that turbidity of raw water is not high (3.84-425) NTU compared with Al-Karkh water project in Baghdad City (6-1400) NTU, because the intakes of WTPs are located in the downstream of Samarra barrage which serves as a pre-sedimentation tank. Low clarifiers turbidity removal efficiencies of $(48.323 \%)$ and $(32.09 \%)$ were obtained for treatment plant and compact unit respectively, while for filters removal efficiencies were $(63.2 \%)$ and $(39.05 \%)$ respectively. The monthly average turbidity of supplied water for conventional water treatment plant and compact unit were (4.3 and 18.2) NTU, the percent of violation to Iraqi Specifications were (29.4\% and 64.7\%) respectively. Not always, increasing in raw water turbidity result in an increase in turbidity removal efficiency. $\mathrm{pH}$ values and TDS concentrations of supplied water are within Iraqi, EPA and WHO Specifications. Low amount and interrupted chlorination in WTP and CU, so, irregular chlorination results in frequent outbreak of waterborne diseases. It can be recommend to improve the water quality monitoring program through the application of; coagulant aids to overcome the high turbidity of raw water during the rainy season, the hexagonal tube settler in the sedimentation tank of the compact unit to get the designed SOR and anthracite with sand as a dual porous media to increase the filtration rate to overcome the shortage in hot seasons. Also periodic systematic maintenance for different units of treatment plants is required.
\end{abstract}

Keywords: Treatment Plant, Turbidity, Samarra City, Raw Water, Filtered Water, Switzerland

\section{Introduction}

Water treatment is originally focused on improving the aesthetic qualities of drinking water. Methods to improve the taste and odor of drinking water were recorded as early as 4000 B.C. Ancient Sanskrit and Greek writings recommended water treatment methods such as filtering through charcoal, exposing to sunlight, boiling and straining. Visible cloudiness (later termed turbidity) was the driving force behind the earliest water treatments. The Egyptians used the chemical alum as early as 1500 B.C. During the 1700s, filtration was established [1]. By the eighteenth century, removal of particles from water by filtration was established as an effective means of clarifying water [2]. Disinfectants like chlorine outbreaks in 
the early 1900s. In 1908 chlorine was used for the first time as a primary disinfectant in Jersey City. The use of other disinfectants such as ozone also began in Europe around this time, but they were not employed in the U.S. until several decades later [1].

The primary goals of a water treatment plant to produce water that is biologically and chemically safe, is appealing to the consumer, and is noncorrosive and non-scaling [3]. The traditional unit processes are rapid mix, coagulation, flocculation, sedimentation, filtration, and disinfection [4]. The treatment of raw water is done by various unit operations (based on physical principles) and unit processes (based on chemical and biological principles) in order to produce water which is safe to drink and meets the safe drinking water standards. [5]. Characteristics of raw water determine the treatment method and human consumption defines the degree of treatment [6]. The treated water should meet the drinking water standards given by various international agencies like the World Health Organization (WHO), US Public Health Standards (USPHS) as well as national agencies of various nations. As global population grows and many developing countries modernize, the importance of water supply and water treatment becomes a much greater factor in the welfare of nations. In today's world the competition for water resources coupled with the unfortunate commingling of wastewater discharges with freshwater supplies creates additional pressure on treatment systems [7].

\section{Study Area}

Samarra City is located on the left bank of Tigris River to the north of Baghdad by $123 \mathrm{~km}$. There are only two treatment plants. The first is the main conventional water treatment plant in the northwest of the city constructed in 1984 with a capacity of $(2400) \mathrm{m}^{3} / \mathrm{hr}$. The second is a compact unit located in the southwest of the city of (200) $\mathrm{m}^{3} / \mathrm{hr}$. capacity constructed in 2001 .

\subsection{Conventional Water Treatment Plant}

The intake of treatment plant which located (100) m downstream of Samarra barrage consists of (400) $\mathrm{mm}$ suction pipe connected to low lift pump station of (4) centrifugal pumps $\left(800 \mathrm{~m}^{3} / \mathrm{hr}\right.$., $40 \mathrm{~m}$ head $)$. Raw water convey by pipe (700) $\mathrm{mm}$ diameter and (1.5) km length to concrete flash mixer tank ( $6 \times 5 \times 6 \mathrm{~m}$ depth), then to three distribution basins $(1.3 \times 1.3) \mathrm{m}$ connected to a clarifier. Two square concrete tanks $(3 \times 3 \times 4 \mathrm{~m})$ used for preparation of alum solution using a mechanical mixers. There are three circular concrete clariflocculators (34 $\mathrm{m}$ diameter and $4 \mathrm{~m}$ depth) having external chamber of $(1.2 \times 1.2 \times 4.4 \mathrm{~m})$ receive raw water from flash mixer and then to the center of flocculation tank (12 m diameter) which contain three vertical mechanical paddles. The clarified water is collected at the top of the tank into a peripheral launder through a vnotch weir, then to the filter blocks. The surface overflows rate (SOR) was $(24.15) \mathrm{m} / \mathrm{d}$ and weir overflow rate (184.08) $\mathrm{m} / \mathrm{d}$. Filters are divided into two cells; each cell has five down flow rapid gravity sand filters $(0.75 \mathrm{~m}$ sand and 0.6 $\mathrm{m}$ gravel) with area $(51.75) \mathrm{m}^{2}$ and filtration rate of (111.3) $\mathrm{m} / \mathrm{d}$. Backwashing process consists of blowing air and reverse filtered water.

There are four chlorinators $(8 \mathrm{~kg} / \mathrm{hr}$.) for pre and postchlorination. Two underground reinforced concrete reservoirs each $(23 \times 14 \times 6 \mathrm{~m})$ with total capacity (3864) $\mathrm{m}^{3}$. High lift pump station consist of (4) horizontal centrifugal pumps $\left(800 \mathrm{~m}^{3} / \mathrm{hr}\right.$. and $60 \mathrm{~m}$ head) supplying water to city.

\subsection{Compact Unit}

The intake which located (1.5) $\mathrm{km}$ downstream from the above intake consists of two submergible pumps $\left(200 \mathrm{~m}^{3} / \mathrm{hr}\right.$. and $40 \mathrm{~m}$ head) convey water to the flash mixers by pipe (300) $\mathrm{mm}$ diameter and (300) $\mathrm{m}$ length. Compact unit consists of two flocculator tanks, two sedimentation tanks, and two pressure filters. The two clarifiers consist of flash mixer $(0.9 \times 1 \times 2 \mathrm{~m})$ with a mechanical propeller mixer, flocculation basin $(0.9 \times 10.75 \times 2 \mathrm{~m})$, and settling tank $(9.55 \times 1.26 \times 1.4 \mathrm{~m})$ which contains a hexagonal tube settler (90 PVC folded sheets). But in actual situation the operators have removed the tube settlers. Collection tank $(2.5 \times 2 \times 2 \mathrm{~m})$ connected to two horizontal centrifugal pumps $(200 \mathrm{~m} 3 / \mathrm{hr}$. and $40 \mathrm{~m}$ head) pump clarified water to the two single media pressure filters $(2.2 \mathrm{~m}$ diameter and 6 $\mathrm{m}$ length ) and (181.82) $\mathrm{m} / \mathrm{d}$ filtration rate, then to the distribution network.

\section{Method}

Samples were collected from different units of treatment plant and compact unit. The collected water data cover some of the important physical and chemical parameters of water quality. The samples were collected approximately weekly according to the operation of water treatment plants (17 runs) for the period from December 2004 to May 2005. The investigated survey samples taken include samples from water treatment plants units to study the performance of the plants. The samples were taken before and after clarification, filtration and from underground storage tank per each run. Table-1 shows date of samplings. 
Table 1. The date of runs number of sampling

\begin{tabular}{llllllll}
\hline Run No. & Date & Run No. & Date & Run No. & Date & Run No. & Date \\
\hline 1 & $01 / 12 / 2004$ & 6 & $23 / 01 / 2005$ & 11 & $13 / 03 / 2005$ & 16 & $05 / 05 / 2005$ \\
2 & $10 / 12 / 2004$ & 7 & $02 / 02 / 2005$ & 12 & $23 / 03 / 2005$ & 17 & $16 / 05 / 2005$ \\
3 & $22 / 12 / 2004$ & 8 & $11 / 02 / 2005$ & 13 & $03 / 04 / 2005$ & & \\
4 & $02 / 01 / 2005$ & 9 & $21 / 02 / 2005$ & 14 & $12 / 04 / 2005$ & & \\
5 & $12 / 01 / 2005$ & 10 & $02 / 03 / 2005$ & 15 & $24 / 04 / 2005$ & & \\
\hline
\end{tabular}

\section{Analysis and Discussions}

\subsection{Analysis of Raw Water Turbidity Data}

A plot of raw water turbidity data at the intakes of Samarra conventional water treatment plant and compact unit are shown in Fig. (1) and Fig. (2) Respectively. These figures show an increasing level in the turbidity in February and March during the rainy seasons and snow melting in the upstream of Tigris river catchment area. The ranges of turbidity were (3.84-425) NTU with mean value (58.274) NTU and (3.95-416) NTU with a mean value of (54.78) NTU respectively, which were less than the range of turbidity at Al-Karkh water treatment plant of Baghdad City (6-1400) NTU [8]. The intakes are located downstream of Samarra barrage and the upstream basin is a large and shallow basin serves as a pre-sedimentation basin.

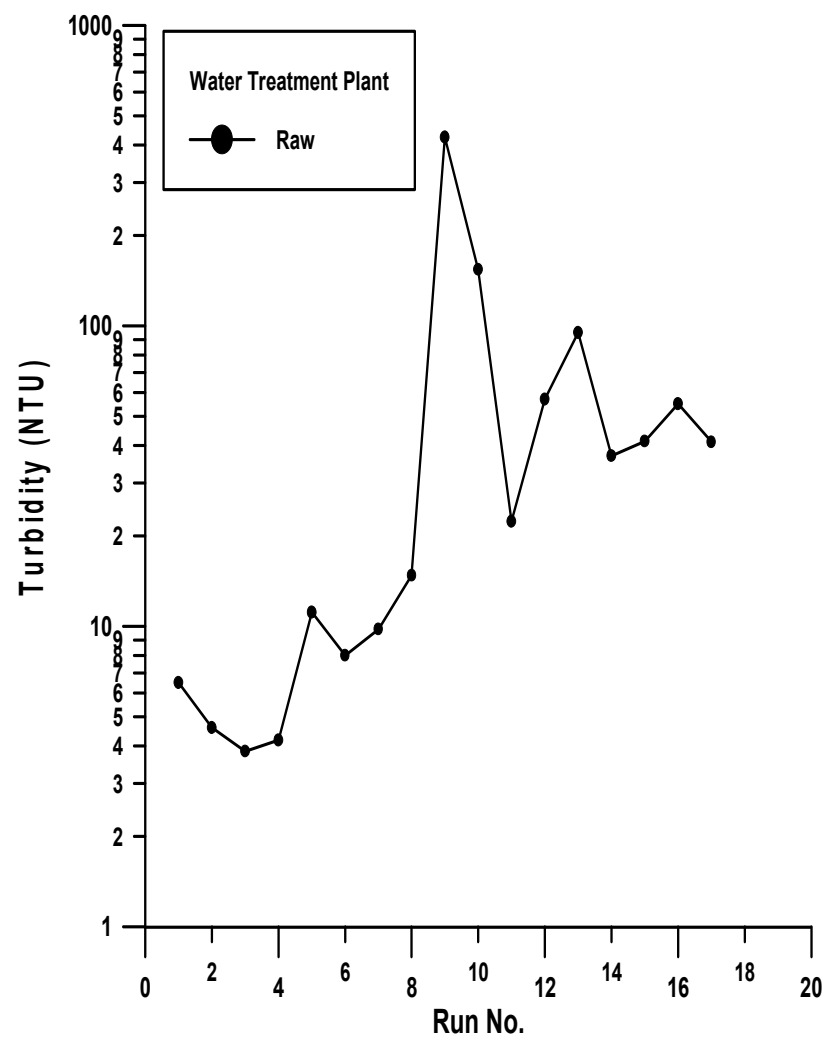

Fig (1). Raw water turbidity at intake of conventional treatment plant

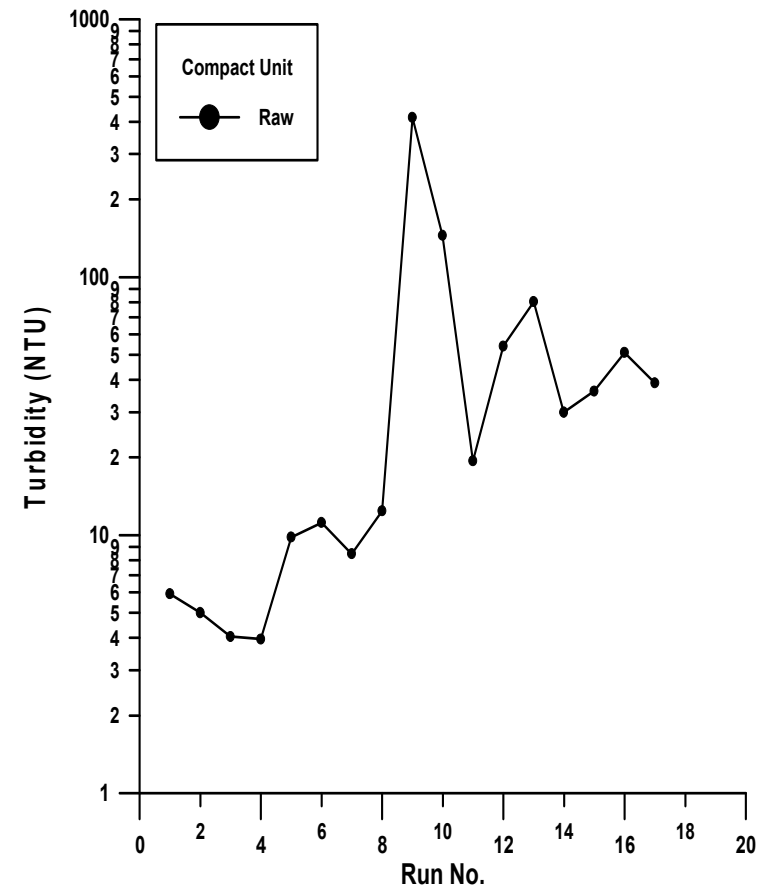

Fig (2). Raw water turbidity at intake of compact unit treatment plant

\subsection{Turbidity Removal Efficiency}

\subsubsection{Conventional Water Treatment plant}

Turbidity removal efficiencies of clarified water ranging from $(10.15-79.06 \%)$ with a mean of $(48.323 \%)$ as shown in Fig. (3) which is lower than (90\%) turbidity removal that must be removed in coagulation and sedimentation as stated by [9]. In spite of low raw water turbidity for runs no. (1-7) the removal efficiency does not exceed (51\%). Low performance of clarifiers and fluctuations in turbidity removal efficiency are attributed to the randomly addition of alum without regarding the turbidity of raw water.

Turbidity removal efficiency performed by filters is shown in figure (4) which are ranges from (13.04- 97.47\%) with a mean of $(63.2 \%)$. It can be concluded that there were many points results in low removal efficiency such that clarification process was not working well resulting a high turbid clarified water and this makes a pressure on filters, no monitoring of filtrate turbidity when it exceeds the allowable limit of Iraqi Standards (5 NTU), irregular backwashing without taking into account the correct method and escaping of fine particles during backwashing, and filter media has not been replaced since more than ten years. 
Fig. (5) shows a plot of turbidity and table (2) lists the descriptive statistics of supplied water. The turbidity range (0.49-12.02) NTU with a mean value of (4.051) NTU and a standard deviation of (2.727), that complied with Iraqi Standard Specifications (5 NTU). Five runs violate the specifications which result in a percent of violation to specifications by $(29.4 \%)$. Sometimes supplied water is more turbid than filtered water due to the accumulation of sediments and turbid materials in the storage tank when the turbidity of filtered water exceeds the standards.

\subsubsection{Compact Unit}

A plot of turbidity removal efficiency produced from two rectangular sedimentation tanks is shown in Fig. (6). Removal efficiency range $(0-78.85 \%)$ with mean value $(32.093 \%)$ which is very much lower than $(90 \%)$ as specified before. The zero values mean that there was no sedimentation process because operation staffs have removed the PVC hexagonal tube settler from the sedimentation tank which resulted in a very high SOR, so it does not work as it was designed. Maximum removal efficiency (78.85\%) occurred in run no. (9) was due to high turbidity of raw water in February. The figure shows sharp fluctuation in removal efficiency due to the random addition of alum.

Removal efficiency produced from filters shown in Fig. (7) ranged from $(14.77 \%-84.9 \%)$ with a mean value of $(39.055 \%)$.. The performance of clarifiers and pressure filters is not acceptable especially when turbidity of raw water increased to (191) NTU in February. Fig. (8) shows a plot of turbidity and table (3) lists the descriptive statistics of supply water. Turbidity ranges from (1-72) NTU with a mean value of (16.386) NTU and a standard deviation (19.01) NTU, which exceed Iraqi Standard Specifications.

The performance of the compact unit is clear from the standard deviation, which indicates high variation of performance. The turbidity of supply water exceeded the standards in (11) runs which results in $(64.7 \%)$ violation. As in water treatment plant the maximum turbidity of supply water occurred at the maximum value of raw water turbidity and clarified water turbidity (416) and (88) respectively. WHO, Guideline for Drinking Water Quality vol. $1 \& 2$ ensure that turbidity of domestic water supplies is virtually absent as a desirable and permissible value.

To give a clear picture about the performance of treatment plants figures (9) and (10) show raw and supplied water of these two plants respectively. Not always the increasing of raw water turbidity increases the turbidity of supplied water, as seen in figure (9), run no. 13 there is a specific limit for purification processes for these plants. For the reasons mentioned before, the performance is low especially that of the compact unit.

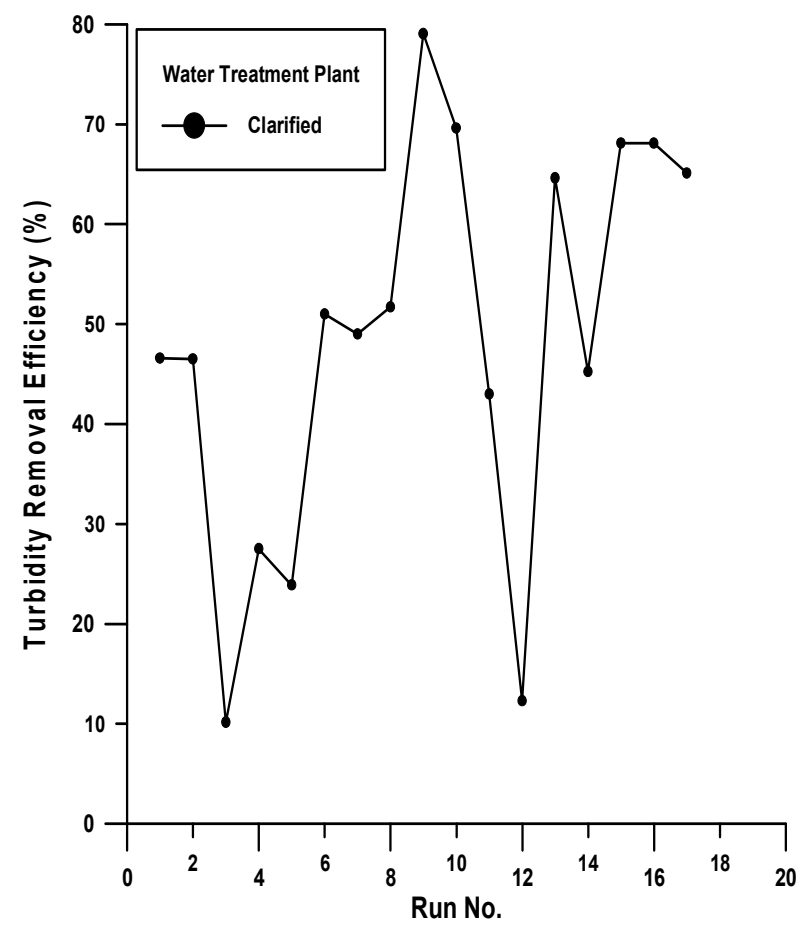

Fig (3). Clarified water turbidity removal efficiency of conventional treatment plant

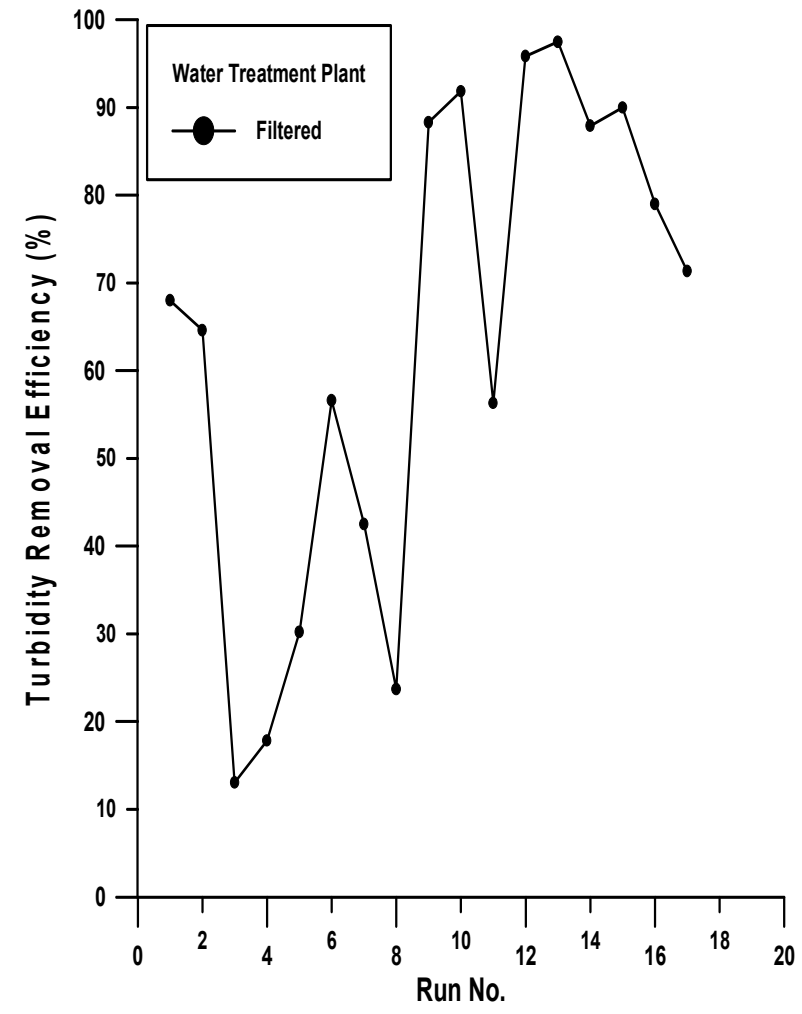

Fig (4). Filtered water turbidity removal efficiency of conventional treatment plant 


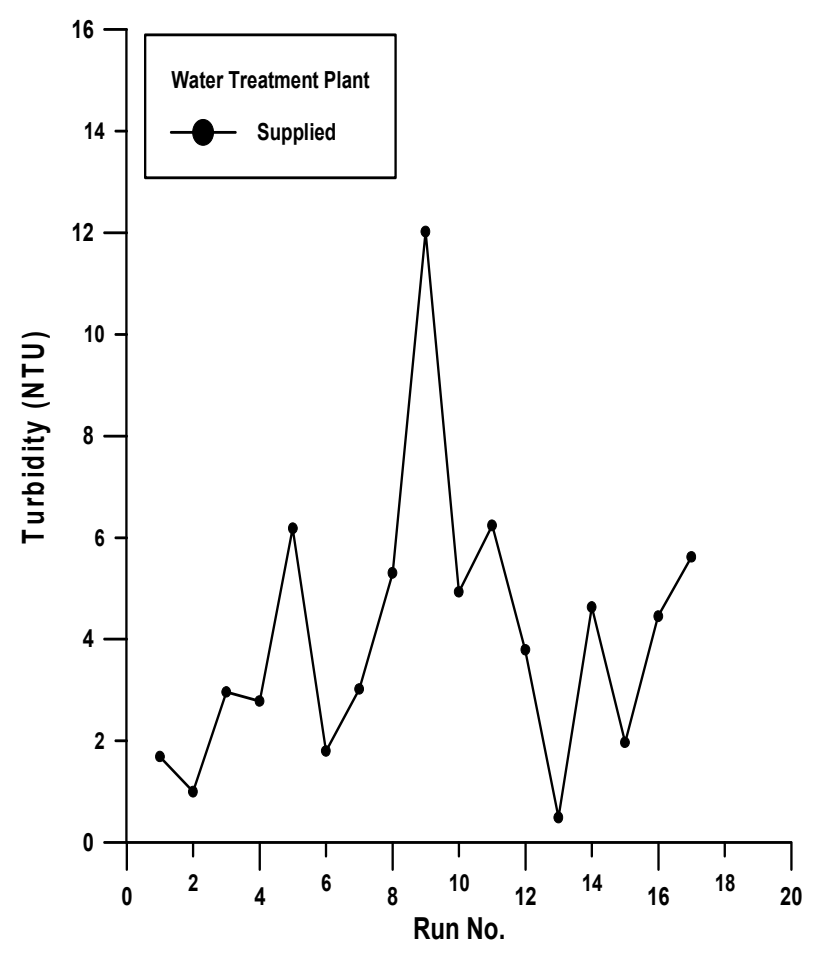

Fig (5). Supplied water turbidity removal efficiency of conventional treatment plant

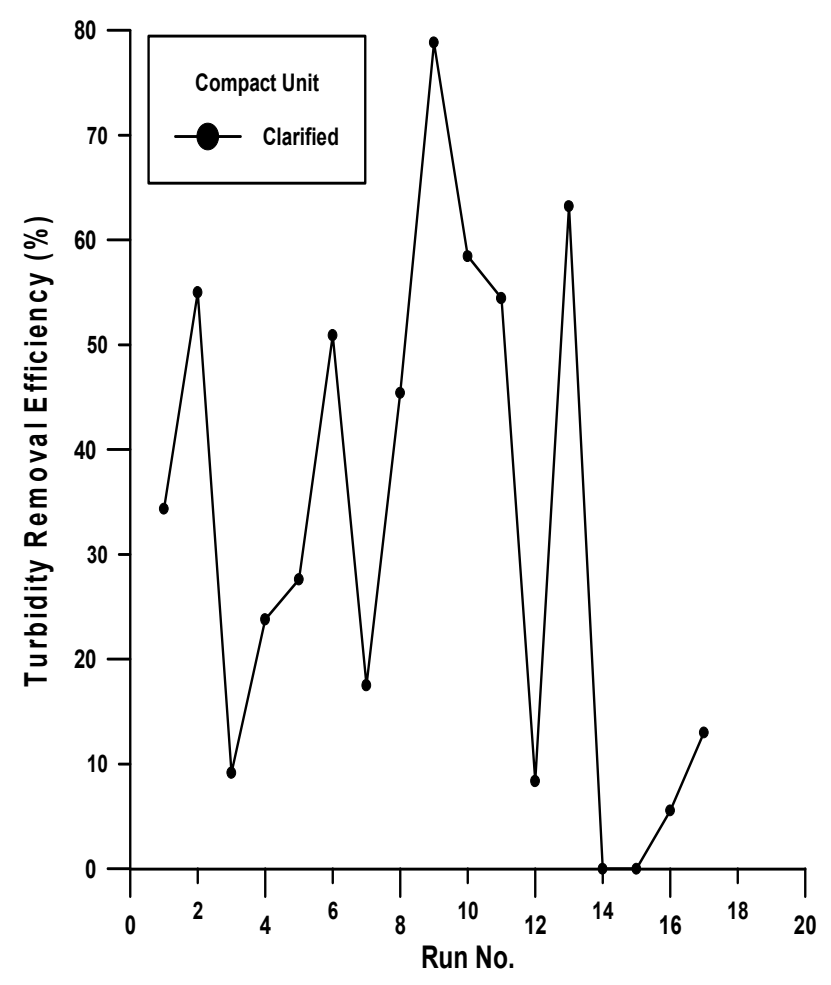

Fig (6). Clarified water turbidity removal efficiency of compact unit

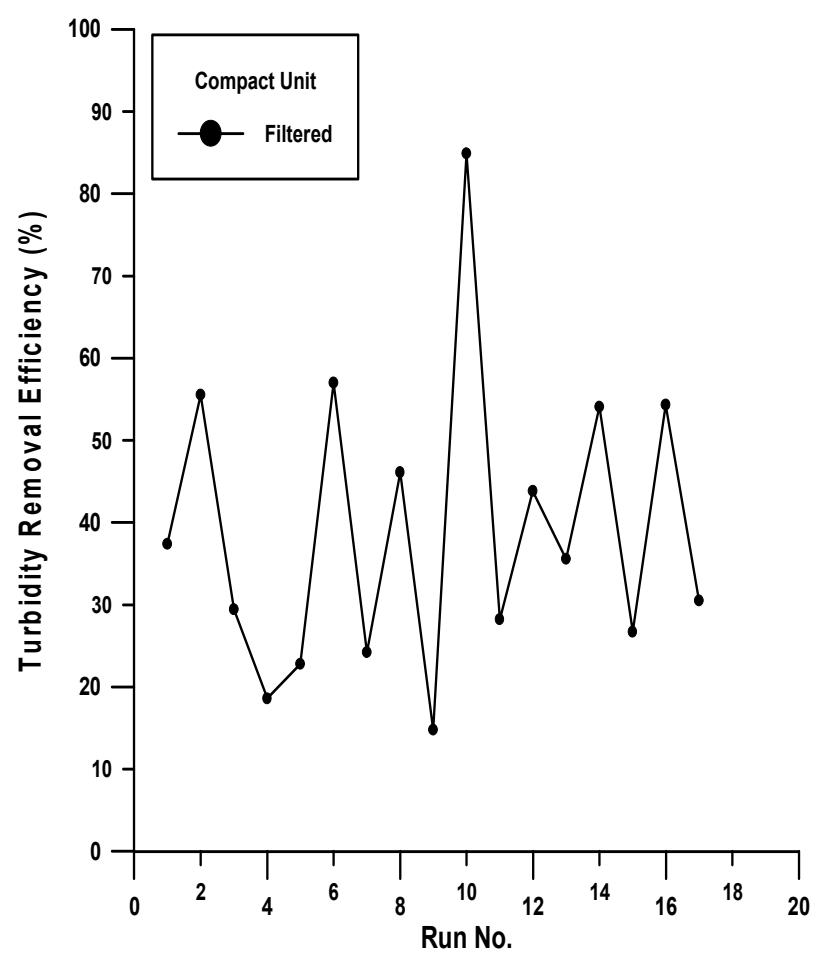

Fig(7). Filtered water turbidity removal efficiency of compact unit

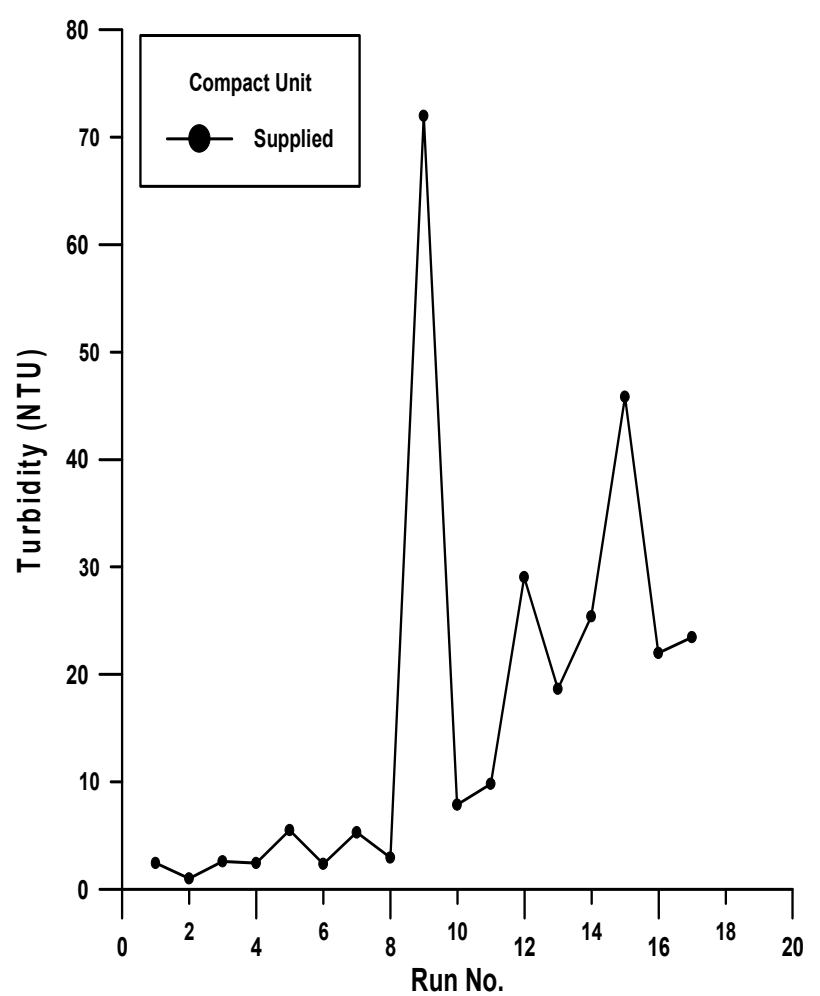

Fig (8). Supplied water turbidity removal efficiency of compact unit 


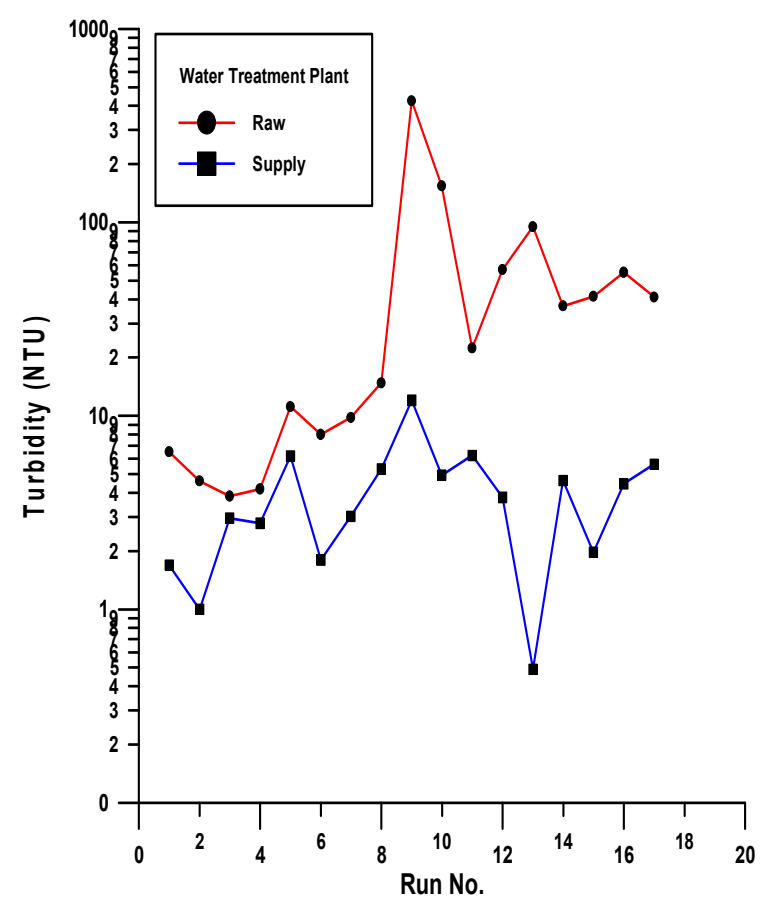

Fig (9). Turbidity of raw and supply water of conventional treatment plant

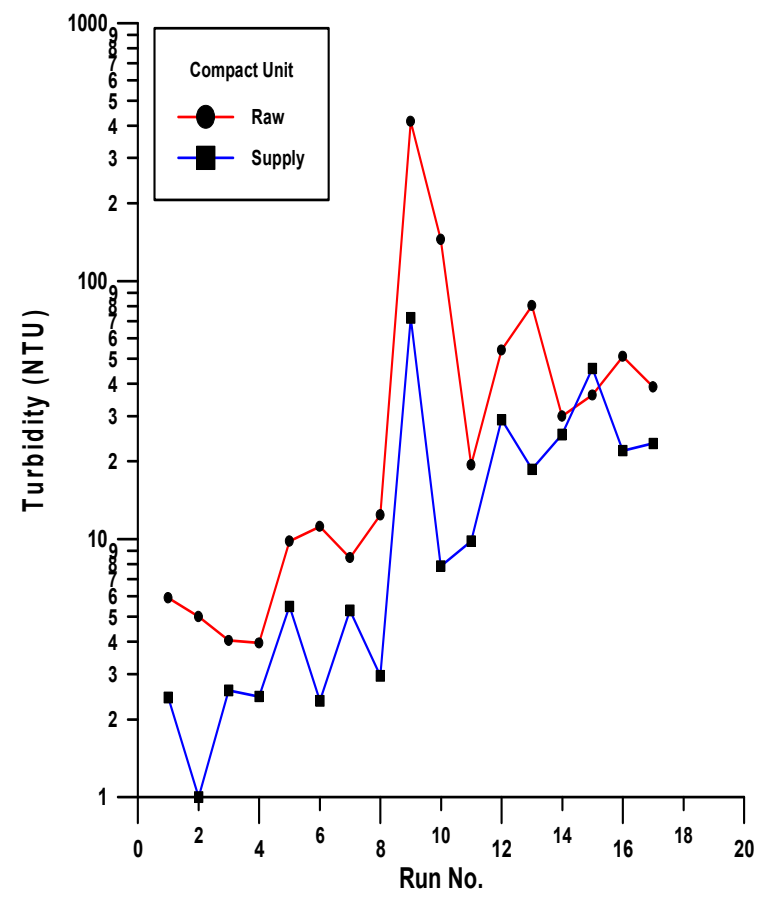

Fig (10). Turbidity of raw and supply water of compact unit

\subsection{Some Water Quality Parameters for Stages of Treatment}

The performance of each unit of treatment plants is studied for different seasons. Figures (11) to (22) show plots of the monthly averages of the studied water quality parameters (temperature, TDS, $\mathrm{pH}$ and residual chlorine). Each figure represents the monthly average of one season.

Figures (11) to (14) show plots of temperature during treatment stages for water treatment plant and compact unit respectively. There is an insignificant temperature variation during the stages of treatment because water is in a continuous movement from one stage to another without stagnation to gain or lose temperature. Both mean values shown in tables (2) and (3) are less than (15) $\mathrm{C}^{\circ}$, which represent the aesthetic objective. Low temperature aids in the retention of residual chlorine by reducing the rate of reaction leading to hypochlorous acid removal; economic losses due to corrosion are reduced at low temperature; the growth of nuisance organism is also inhibited [10].

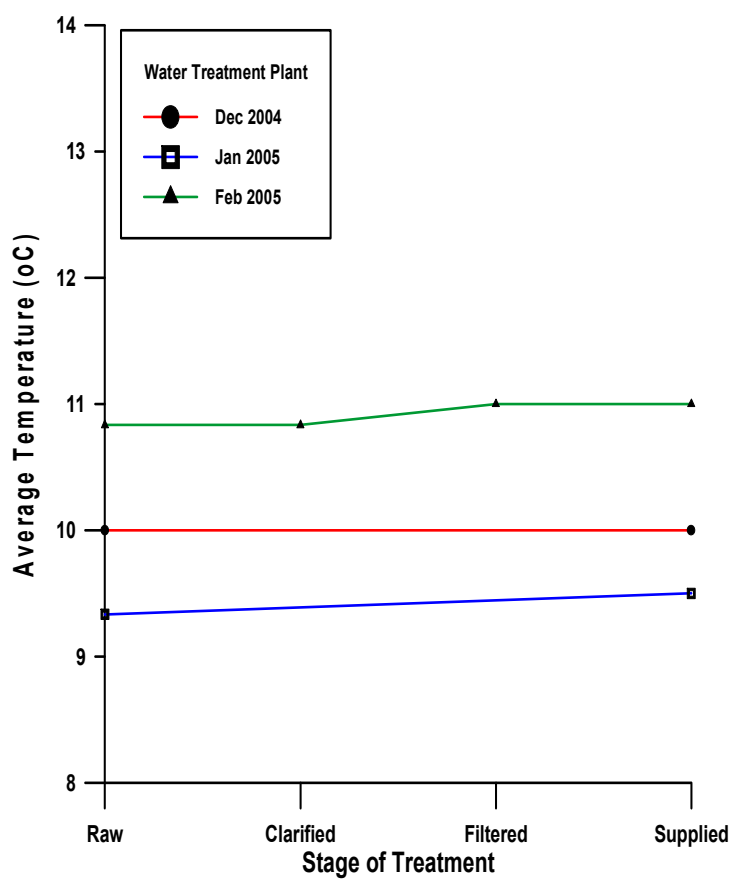

Fig (11). Monthly average temperature of treatment plant stages during winter season

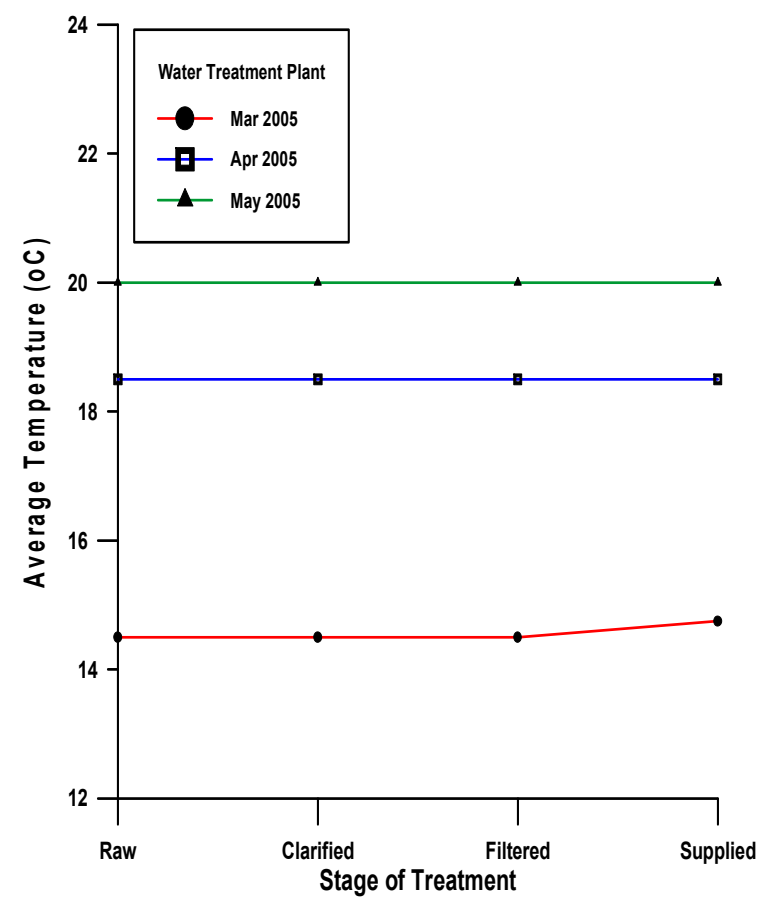

Fig (12). Monthly average temperature of treatment plant stages during spring season 


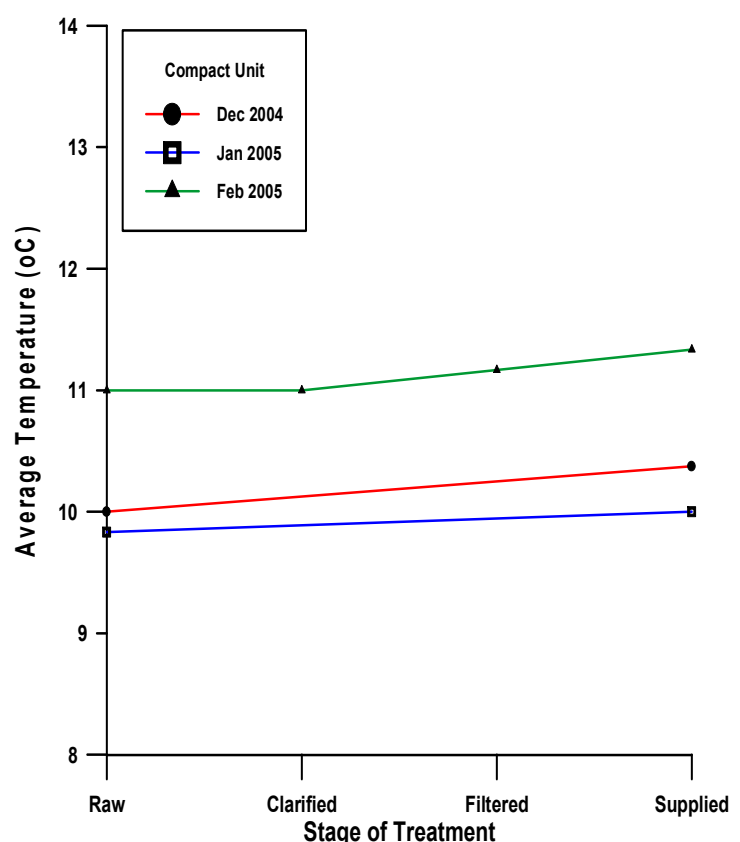

Fig (13). Monthly average temperature of compact unit stages during winter season

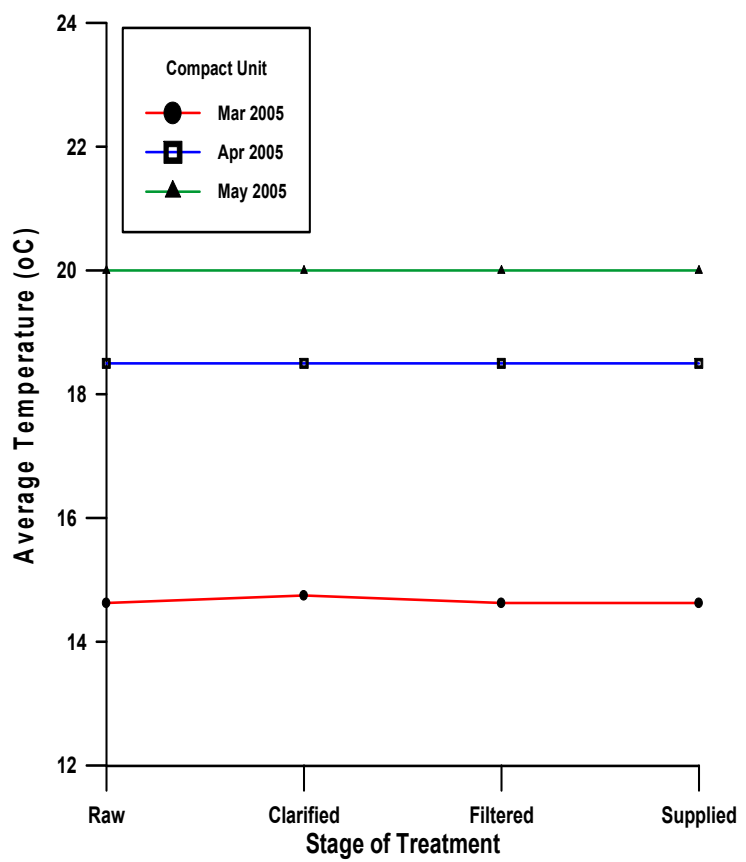

Fig (14). Monthly average temperature of compact unit stages during spring season

Plots of TDS data for stages of treatment are shown in figures (15) to (18). There is an insignificant variation in TDS concentration due to the conventional type of plants, except, it was found in the last four months, that, there was a decrease in TDS concentration by $(10) \mathrm{mg} / \mathrm{L}$ in clarified water of treatment plant from that in raw water. TDS comprise inorganic salts and a small amount of organic matter that are dissolved in water [11] (MDWQMG, 2004). So this small amount of dissolved TDS has oxidized by pre-chlorination process and removed through coagulation and sedimentation processes.
Tables (2) and (3) show that ranges of concentration of supplied water (211-277) $\mathrm{mg} / \mathrm{L}$ and (211- 277) $\mathrm{mg} / \mathrm{L}$, mean values of (248.4) $\mathrm{mg} / \mathrm{L}$ and (254.76) $\mathrm{mg} / \mathrm{L}$, and a standard deviation (19.98) and (19.747) respectively. There is a clear decrease in TDS concentration of raw water in spring season because of snow melting in catchment area by enhancing with fresh water with a very low TDS concentration (the measured TDS of rainwater is $12 \mathrm{mg} / \mathrm{L}$ ). TDS concentrations were more than the desirable (200) $\mathrm{mg} / \mathrm{L}$ and less than the permissible (500) $\mathrm{mg} / \mathrm{L}$ of $\mathrm{WHO}$ Specifications and less than Iraqi Standard Specifications (1000) $\mathrm{mg} / \mathrm{L}$ and EPA Specifications (500) $\mathrm{mg} / \mathrm{L}$.

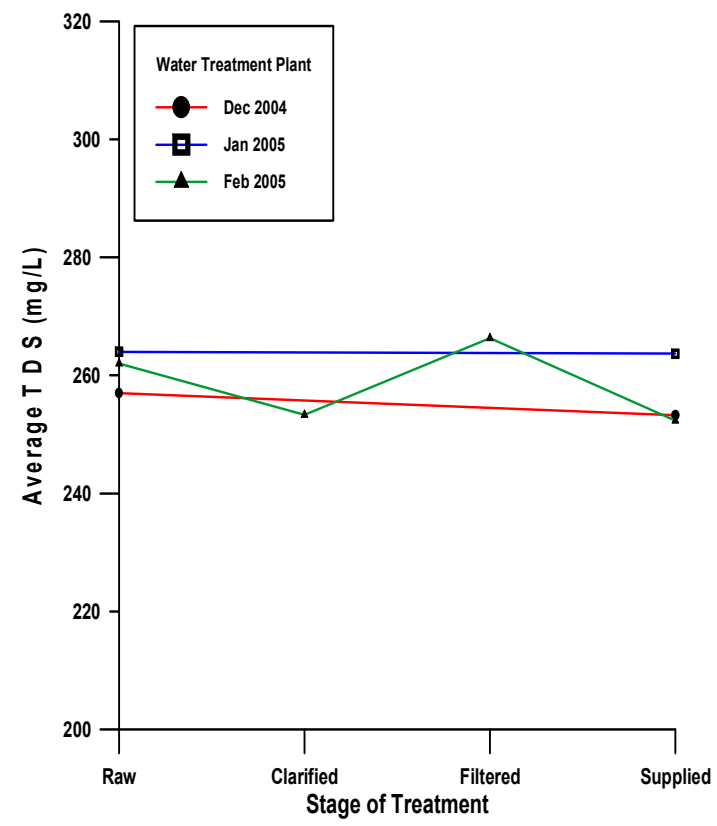

Fig (15). Monthly average TDS of treatment plant stages during winter season

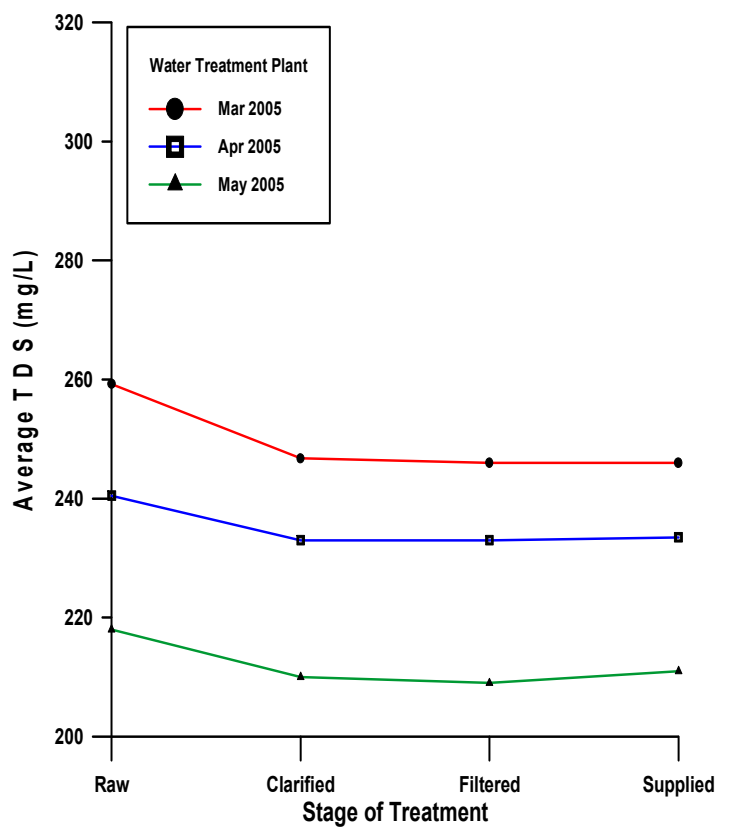

Fig (16). Monthly average TDS of treatment plant stages during spring season 


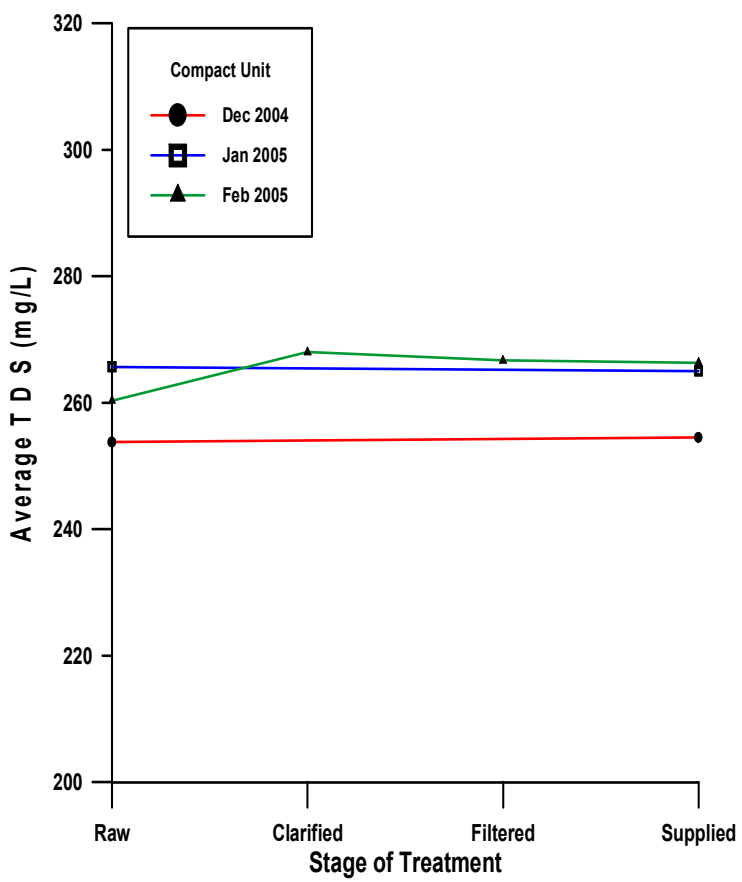

Fig (17). Monthly average TDS of compact unit stages during winter season

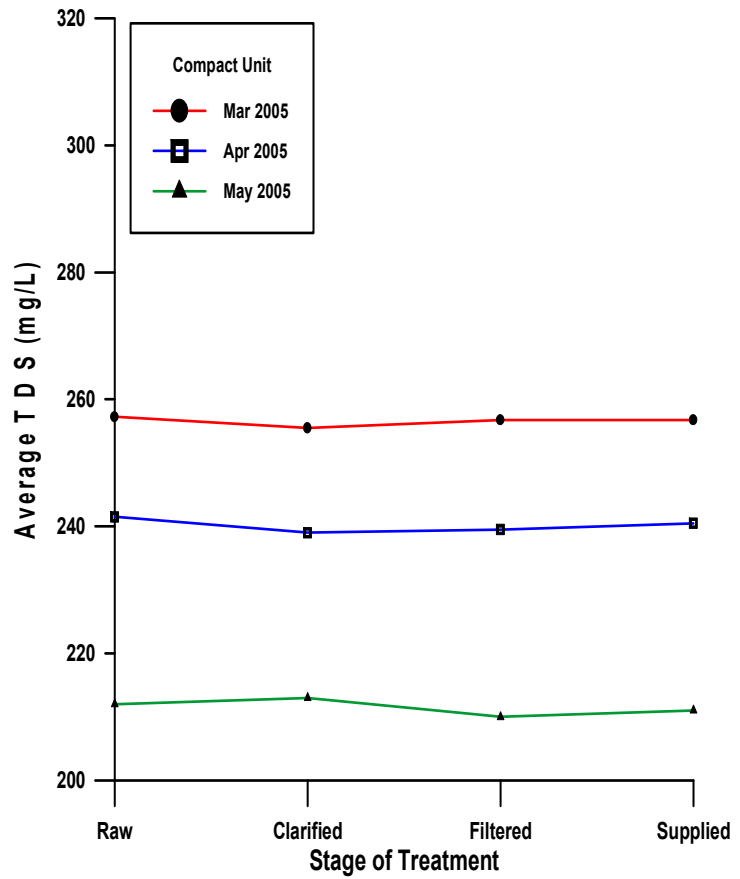

Fig (18). Monthly average TDS of compact unit stages during spring season

Also there is insignificant $\mathrm{pH}$ variation in both plants as shown in figures (19) to (22) because

The source of raw water is a surface water source, which is frequently saturated with dissolved oxygen, and does not contain organic acids from decaying vegetation or ground water which is almost saturated with carbon dioxide from bacterial oxidation. Also the amount of alum added is very low and constant $(250) \mathrm{kg} / \mathrm{d}$, resulted in alum dose (5.2) $\mathrm{mg} / \mathrm{L}$. Descriptive statistics of supplied water shown in tables (2) and (3) give range of $\mathrm{pH}$ values (7.72-8.34) with mean (8.15) and a standard deviation (0.16268) and (7.73$8.37)$ with mean (8.144) and a standard deviation (0.176) respectively.

There is a decrease in $\mathrm{pH}$ values especially in May due to snow melting but all values of $\mathrm{pH}$ are within the desirable and permissible limits of WHO Specifications (68.5) and Iraqi and EPA Specifications (6.5-8.5). This $\mathrm{pH}$ range is appropriate for high efficiency of coagulation and flocculation processes. By keeping $\mathrm{pH}$ below (8.5), the rate of disinfection is increased.

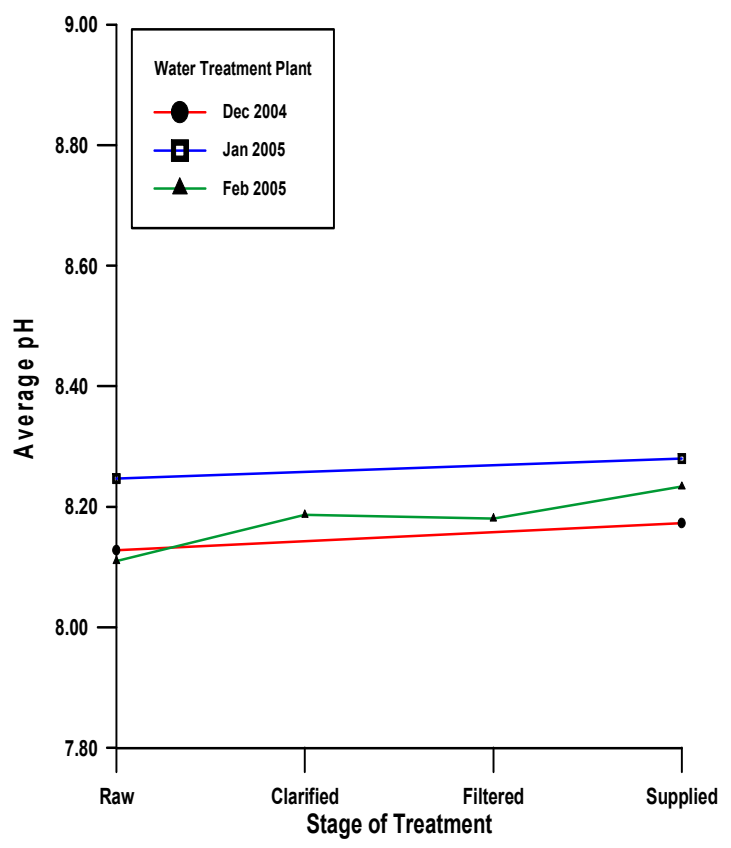

Fig (19). Monthly average $\mathrm{pH}$ of treatment plant stages during winter season

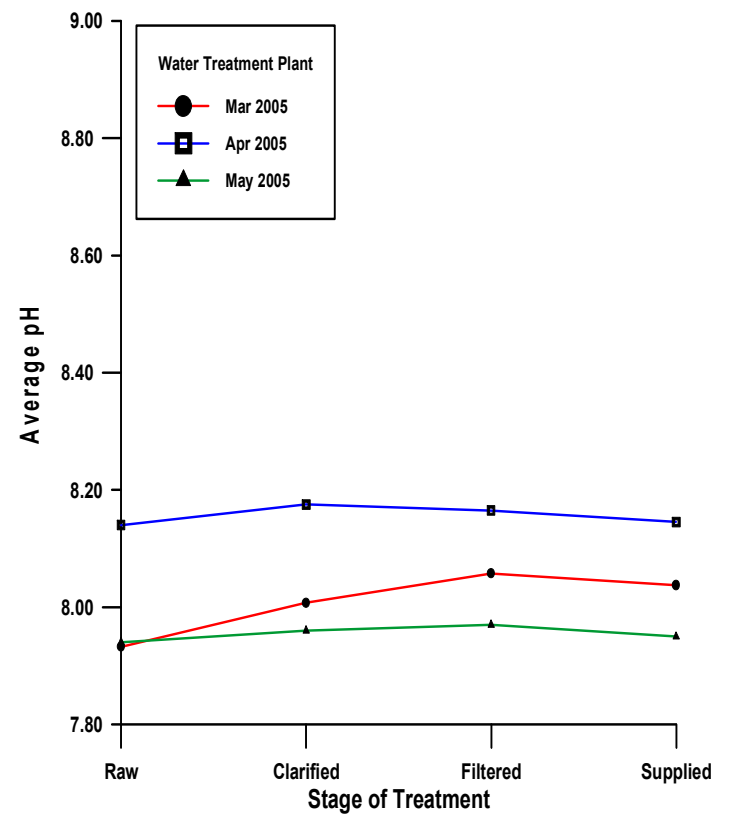

Fig (20). Monthly average pH of treatment plant stages during spring season 


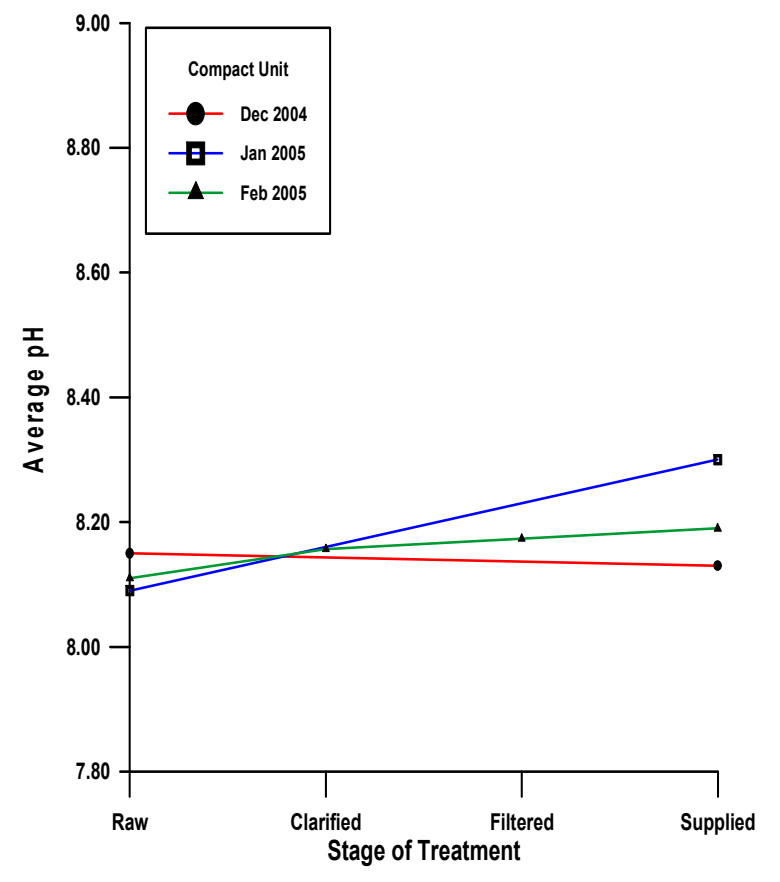

Fig (21). Monthly average $\mathrm{pH}$ of compact unit treatment stages during winter season

In conventional water treatment plant only (7) runs out of (17) runs disinfectant was added which give a percent of (41\%) while in compact unit added only in (11) runs $(65 \%)$. Residual chlorine ranged from $(0-2) \mathrm{mg} / \mathrm{L}$ with a mean value of $(0.735) \mathrm{mg} / \mathrm{L}$ and a standard deviation $(0.9163)$

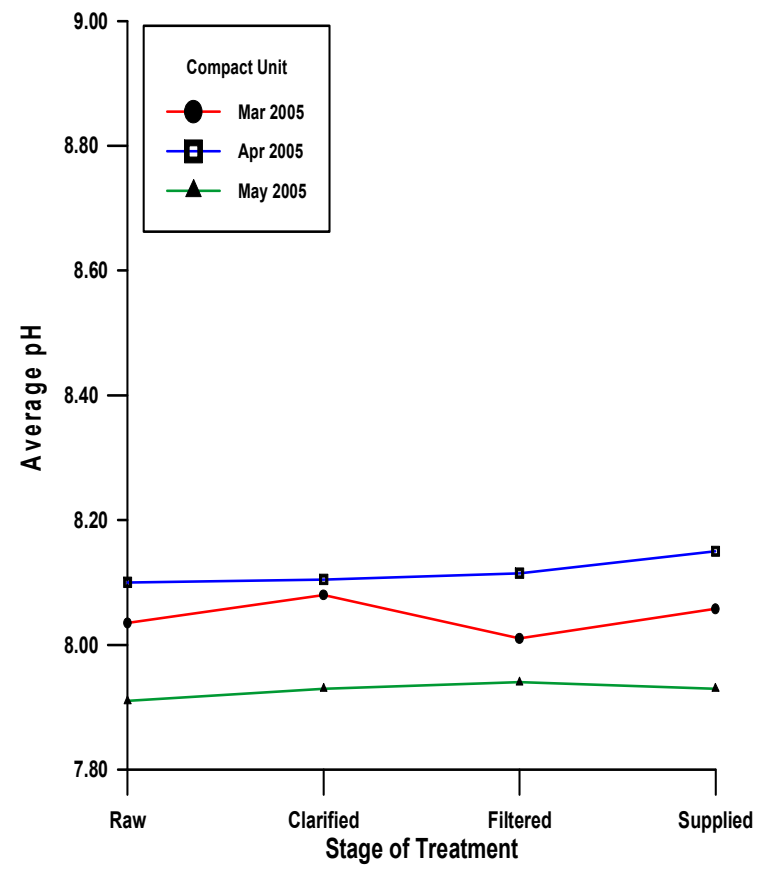

Fig (22). Monthly average $p H$ of compact unit treatment stages during spring season

and $(0-3) \mathrm{mg} / \mathrm{L}$ with a mean value of (1.19) $\mathrm{mg} / \mathrm{L}$ and a standard deviation (1.03) as shown in tables (2) and (3) respectively. Iraqi Standard Specifications for residual chlorine in supply water permit a limit of $(0.3-2) \mathrm{mg} / \mathrm{L}$.

Table (2). Descriptive statistics of supplied water from water treatment plant.

\begin{tabular}{|c|c|c|c|c|c|c|c|c|c|c|}
\hline & $\mathbf{N}$ & Min. & Max. & Mean & Std. & Variance & skewness & & Kurtosis & \\
\hline & Statistic & Statistic & Statistic & Statistic & Statistic & Statistic & Statistic & Std. Error & $\begin{array}{l}\text { Statisti } \\
\text { c }\end{array}$ & $\begin{array}{l}\text { Std. } \\
\text { Error }\end{array}$ \\
\hline Temperature & 17 & 8.50 & 20.00 & 12.79 & 3.737 & 13.971 & 0.773 & 0.550 & -0.508 & 1.063 \\
\hline Resd. Chlorine & 17 & 0.00 & 2.00 & 0.735 & 0.916 & 0.840 & 0.467 & 0.550 & -1.926 & 1.063 \\
\hline $\mathrm{pH}$ & 17 & 7.72 & 8.34 & 8.154 & 0.163 & 0.026 & -1.308 & 0.550 & 1.911 & 1.063 \\
\hline Turbidity & 17 & 0.49 & 12.02 & 4.051 & 2.727 & 7.439 & 1.471 & 0.550 & 3.607 & 1.063 \\
\hline T D S & 17 & 211.0 & 277.0 & 48.41 & 9.985 & 399.382 & -0.809 & 0.550 & -0.402 & 1.063 \\
\hline Valid N & 17 & & & & & & & & & \\
\hline
\end{tabular}

Table (3). Descriptive statistics of supplied water from compact unit treatment plant.

\begin{tabular}{|c|c|c|c|c|c|c|c|c|c|c|}
\hline \multirow{2}{*}{$\mathrm{b}$} & \multirow{2}{*}{$\begin{array}{l}\text { N } \\
\text { Statistic }\end{array}$} & \multirow{2}{*}{$\begin{array}{l}\text { Min. } \\
\text { Statistic }\end{array}$} & \multirow{2}{*}{$\begin{array}{l}\text { Max. } \\
\text { Statistic }\end{array}$} & \multirow{2}{*}{$\begin{array}{l}\text { Mean } \\
\text { Statistic }\end{array}$} & \multirow{2}{*}{$\begin{array}{l}\text { Std. } \\
\text { Statistic }\end{array}$} & \multirow{2}{*}{$\begin{array}{l}\text { Variance } \\
\text { Statistic }\end{array}$} & \multicolumn{2}{|l|}{ skewness } & \multicolumn{2}{|l|}{ Kurtosis } \\
\hline & & & & & & & Statistic & $\begin{array}{l}\text { Std. } \\
\text { Error }\end{array}$ & Statistic & Std. Error \\
\hline Temperature & 17 & 9.00 & 20.0 & 13.00 & 3.549 & 12.594 & 0.856 & 0.550 & -0.305 & 1.063 \\
\hline Resd. Chlorine & 17 & 0.00 & 3.00 & 1.191 & 1.029 & 1.059 & 0.221 & 0.550 & -1.368 & 1.063 \\
\hline pH & 17 & 7.73 & 8.37 & 8.144 & 0.176 & 0.031 & -0.889 & 0.550 & 0.134 & 1.063 \\
\hline Turbidity & 17 & 1.00 & 72.0 & 16.39 & 19.10 & 364.900 & 1.833 & 0.550 & 3.612 & 1.063 \\
\hline T D S & 17 & 211.0 & 279.0 & 254.7 & 19.75 & 389.941 & -1.246 & 0.550 & 0.679 & 1.063 \\
\hline Valid N & 17 & & & & & & & & & \\
\hline
\end{tabular}




\section{Conclusions}

The turbidity of raw water is not high (3.84-425) NTU compared with Al-Karkh water project (6-1400) NTU which is located north Baghdad city, because the intakes located downstream Samarra barrage which serves as a presedimentation tank. Low clarifiers and filters turbidity removal efficiencies of both conventional treatment plant and compact unit ranged from $(10.15 \%-79.06 \%)$ and $(0$ $78.85 \%)$ respectively and (13.04-97.47\%) and (14.77$84.9 \%$ ) for filters respectively.

The percentage of supplied water turbidity violation to Iraqi Specifications for water treatment plant and compact unit were $(29.4 \%$ and $64.7 \%)$ respectively and the monthly average turbidities were (4.3 and 18.2) NTU respectively. $\mathrm{pH}$ and TDS concentrations of supplied water were within Iraqi, EPA and WHO Specifications. Low amount and interrupted chlorination in both treatment systems, so, irregular chlorination results in frequent outbreak of waterborne diseases.

From the above study it can be recommend that a program of regular monitoring of water quality must be formulated and implemented. The use of coagulant aids to overcome the high turbidity of raw water during the rainy season. Upgrading the treatment plants by adding inclined plate to clarifiers and emphasizing the use of the tube settler in the sedimentation tank of the compact unit to get the designed SOR, and the use of dual filter media to increase the filtration rate is very important. Also Periodic systematic maintenance for different stages of treatment is required.

\section{References}

[1] Environmental Protection Agency (EPA), The History of Drinking Water Treatment, 2000

[2] Borchardt, J. A., and G. Walton, Water Quality In Water Quality and Treatment, American Water Works Association, Ed. 3rd edition. New York: McGraw-Hill. 1971,

[3] Cheremisinoff, N.P, Handbook of Water and Wastewater Technologies, Butterworth-Heinemann Publications, 2002

[4] Robert A. Clark, Virendra Sethi, David L., and James A.Williams, , Water Supply, Standard Handbook of Environmental Engineering, 2nd edition, Mc Grow Hill Handbooks, 2004

[5] C.P. Kaushik, S.S Bharikatti, and Anubha Kaushik, Basic Civil and Environmental Engineering", New AGE International (P) Limited, Publishers, 2010

[6] Ruth F.Weiner and Robin A. Mathews, Environmental Engineering, 4th edition, Butterworth Heinemann, 2003

[7] Nelson L.Nemerow, Franklin J, Agardy Patrick Sullivan, and Joseph A, Salvato, Environmental Engineering, 6th edition, John Wiley \& Sons, Inc., 2009

[8] Janna, H.A., "Evaluation of Tigris River Water Quality at Baghdad and the Performance of the Existing Water Treatment Plants", M .Sc, Thesis, University of Technology, 2004

[9] Tebbutt, T. H. Y, Principles of Water Quality Control, 5th edition, Butterworth. Pontius, 1998

[10] Mullen, E.D. and Ritter, J.A, 1974, Potable water corrosion control, .J. AWWA, (1974) 66:473.

[11] Municipal Drinking Water Quality Monitoring Guidelines (MDWQMG), 2004. 